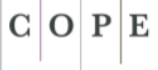

\title{
Recenzja: Robert Kreitz, Ingried Miethe, Anja Tervooren (red.), Theorien in der qualitativen Bildungsforschung - Qualitative Bildungsforschung als Theoriegenerierung, Opladen Berlin Toronto 2016, Verlag Barbara Budrich, ss. 256
}

\begin{abstract}
Abstrakt
Tekst jest recenzją monografii pod redakcją Roberta Kreitza, Ingried Miethe, Anji Tervooren, wydanej przez Kommision für qualitative Bildungs- und Biographieforschung Deutsche Gesellschaft für Erziehungswissenschaf. 12 artykułów zamieszczonych w książce dotyczy: 1) empirycznych konsekwencji teoretycznych stanowisk przyjmowanych przez badaczy; 2) teoretycznych innowacji w badaniach jakościowych; 3) innowacji w metodyce badań będących konsekwencją teoretycznych orientacji.
\end{abstract}

Słowa kluczowe: badania jakościowe, badania biograficzne, Bildung, teoria w badaniach empirycznych.

\section{Review: Robert Kreitz, Ingried Miethe, Anja Tervooren} (eds.), Theorien in der qualitativen Bildungsforschung - Qualitative Bildungsforschung als Theoriegenerierung, Opladen Berlin Toronto 2016, Verlag Barbara Budrich, pp. 256

\section{Abstract}

The text is a review of a monograph edited by Robert Kreitz, Ingried Miethe and Anja Tervooren, published by Kommision für qualitative Bildungs- und Biographieforschung Deutsche Gesellschaft für Erziehungswissenschaf. The 12 articles included

\footnotetext{
* Uniwersytet Łódzki.

Artykuł otrzymano: 16.10.2020; akceptacja: 3.11.2020.
} 
in the book concern: 1) empirical consequences of theoretical positions taken by researchers; 2) theoretical innovations in qualitative research; 3) innovations in research methodology resulting from theoretical orientations.

Keywords: qualitative research, biographical research, Bildung, theory in empirical research.

Tytuł przedstawianej książki można przetłumaczyć na język polski jako: Teorie w jakościowych badaniach (procesu) kształtowania - Jakościowe badania (procesu) kształtowania jako generowanie teorii. Przywołanie w pierwszej części tytułu Bildungsforschung wskazuje przedmiot badań, który ma być czynnikiem wyróżniającym zogniskowane na nim projekty badawcze spośród innych badań jakościowych. Jest to o tyle warte zauważenia, że wzmacniany jest empiryczny nurt badania Bildung ${ }^{1}$, tradycyjnie zakotwiczonego w analizach filozoficznych i spekulacjach myślowych. Prezentowane opracowanie otwiera nową serię wydawaną przez jedną z komisji Deutsche Gesellschaft für Erziehungswissenschaf (niemiecki odpowiednik Polskiego Towarzystwa Pedagogicznego) Kommision für qualitative Bildungs- und Biographieforschung (Komisji ds. jakościowych badań procesów kształtowania i badań biograficznych). Druga część tytułu książki nawiązuje do postulatu sformułowanego w latach 60. XX w. przez B. G. Glassera i A. L. Straussa, by traktować badania empiryczne jako źródło nowych teorii przedmiotowych, a nie tylko jako sposób weryfikacji teorii „wyspekulowanych przy biurku”. Ten postulat początkowo zinterpretowany został przez część badaczy jako zalecenie rezygnacji w jakościowych badaniach empirycznych z wszelkich wstępnych teorii. Aktualnie takie stanowisko uznaje się za zbyt radykalne. Wprawdzie nadal podkreśla się teoretyczne niezdeterminowanie badań jakościowych, ale jednocześnie dostrzega rolę przedwiedzy badaczek i badaczy oraz konieczność pojęciowego ujmowania poznawanej rzeczywistości.

We wstępie do monografii zespół redakcyjny sformułował dwa podstawowe pytania: w jaki sposób w teoriach generowanych w trakcie badań jakościowych odzwierciedlają się metodologiczne i metodyczne rozstrzygnięcia oraz jakie są konsekwencje wstępnych założeń (Vorannahmen) oraz teorii przedmiotowych, stanowiących przyjmowane przez badaczki i badaczy punkty odniesienia (Bezugspunkte), zarówno dla wyboru metod badawczych, jak i dla jakości poznania empirycznego. Do tych pytań w różnym stopniu odnosi się 12 artykułów zamieszczonych w opracowaniu. Zostały one podzielone na trzy części: 1) Empiryczne konse-

\footnotetext{
1 Bildung najczęściej tłumaczy się na język polski jako kształcenie. Ale „kształcenie” łączy się zazwyczaj $\mathrm{z}$ formalnymi instytucjami edukacyjnymi, co nie oddaje treści tego teoretycznego pojęcia. Tłumaczę więc Bildung jako „kształtowanie”, mimo że zwłaszcza w złożeniach brzmi niezbyt „fortunnie”. Czasownik bilden znaczy tworzyć, formować - w dalszej kolejności - kształcić. Warto dodać, że w języku niemieckim kształcenie instytucjonalne oddaje słowo Ausbildung. Zdaniem krytyków współczesnego systemu edukacji Ausbildung nie sprzyja Bildung, czasami ten proces wręcz uniemożliwia.
} 
kwencje teoretycznych stanowisk; 2) Teoretyczne innowacje w badaniach jakościowych; 3) Innowacje metodyczne - teoretyczne orientacje.

Część pierwszą rozpoczyna artykuł Bettiny Dausien pt. Rekonstrukcje i refleksje: badania biograficzne odwołujące się do teorii kształtowania a odwołujace się do teorii nauk społecznych. Autorka zestawia ze sobą badania biograficzne usytuowane w różnych teoriach podstawowych, mając świadomość, iż nie ma „punktu”, z którego można by dokonać neutralnego porównywania różnych typów badań biograficznych. Swoją wypowiedź formułuje z pozycji „uczestniczącego obserwatora”, który ma własne doświadczenia badawcze, a jednocześnie stara się uzyskać ogólniejsze rozeznanie. Porównując biograficzne badania, w których centralną kategorią jest Bildung i badania odwołujące się do teorii społecznych, za podstawową różnicę uznaje normatywny wymiar tych pierwszych. Ich autorki i autorzy nie każdą zmianę biograficzną uznają za wyraz Bildung, a „tylko” za uczenie się. Dla ułatwienia polskiemu pedagogowi zrozumienia „istoty” tej różnicy można przywołać pojawiającą się w naszej literaturze częściej niż Bildung koncepcję transformatywnego uczenia się. Jej zwolennicy również chcą empirycznie odróżniać transformatywne uczenie się - uznawane za bardziej znaczące - od nietransformatywnego. Dausien pokazuje ograniczenia obrazu biografii wynikające z normatywnej koncepcji Bildung. Zauważa, że pedagodzy koncentrują się na „zmianach wewnętrznych”, zapominają tym samym, że Bildung prowadzi nie tylko do transformacji siebie, ale także obrazu świata. Autorka stwierdza, że wyjściowe wyobrażenie biografii staje się bogatsze przy szerszym wykorzystywaniu teorii społecznych, trudno bowiem ujmować proces tworzenia się biografii jako wymianę między wolnymi podmiotami, działającymi w przestrzeni pozbawionej struktury. Zdaniem Dausien z wyników badań, odwołujących się do Sozialtheorie, zbyt rzadko korzystają teoretycy wychowania (pedagodzy ogólni) prowadzący badania biograficzne. Znacznie częściej wykorzystują je pedagodzy społeczni, przedstawiciele edukacji dorosłych czy pedagogiki młodzieży. Są również tacy badacze, jak np. Heinz Sünker, dla których praca nad teorią kształtowania jest możliwa tylko wtedy, gdy jednocześnie uwzględnia się teorię społeczeństwa.

Problem zgłoszony przez Dausien konkretyzuje w swoim artykule Dorle Klika (A tergo - eksplikowane i implikowane koncepcje Bildung w pedagogicznych badaniach biograficznych). Pyta, czy można uzgodnić teorię uczenia się Wilfrieda Marotzkiego, uwzględniającą stopnie uczenia się Georga Batesona, ze strukturami procesowymi Fritza Schütze. Dla Marotzkiego kształtowanie to proces doskonalenia - przemiany stosunku człowieka do siebie samego, będący następstwem samorefleksji. Dla Schützego do znaczących zmian prowadzą zarówno (negatywne) doświadczenia trajektorii, jak i (pozytywne) metamorfoz. Dla Marotzkiego kształtowanie wyraża się poprzez nagłe zmiany tożsamości ja, które ograniczają się zasadniczo do obszaru kognitywnego. Autorka zauważa, że nie są to zbyt częste zdarzenia i mogą pojawiać się najwcześniej u młodszej młodzieży. Klika konkluduje, że teoria kształtowania Marotzkiego ogranicza zakres doświadczeń biograficz- 
nych ujmowanych w badaniach empirycznych. Postuluje przekonstruowanie teorii kształtowania, argumentując, że znaczenie kształtujące ma nie tylko refleksja, ale także działanie społeczne oraz relacje z rzeczami. Ten ostatni czynnik jest o tyle ważny w wychowaniu, że rzeczy stawiają człowiekowi opór, nie może dysponować nimi dowolnie, zgodnie z życzeniem. Korzystniej dla poznania jest traktować Bildung jako kategorię deskrypcyjną, której treść stanowi życiowe doświadczenie człowieka, a nie normatywną. Prowokacyjnie stwierdza, że życie człowieka, który stał się mordercą, jest również procesem kształtowania.

Christine Wiezorek (Procesy kształtowania u dzieci (czy ich brak), trajektoryjno-podobny rozwój i biograficzne orientacje) pyta, czy teorie kształtowania wykorzystywane w pedagogicznych badaniach biograficznych są wystraczająco ogólne, by można je stosować zarówno wobec dzieci, młodzieży, jak i dorosłych? Odpowiadając, zgłasza liczne wątpliwości. Procesy dorastania dzieci i młodzieży warunkowane są w dużym stopniu przez czynniki od nich niezależne, ich rozwój tożsamości warunkowany jest przez „to co obce” - dominuje heteronomia, a nie autonomia przewidywana przez teorie kształtowania. Bildung jako transformacja relacji wobec siebie i świata zakłada stan, który można transformować, np. historię własnej socjalizacji. W tym kontekście autorka pyta, czy wiemy, od kiedy dzieci taką historią dysponują? Bildung jako transformatywny proces wymaga refleksyjności, językowej dyspozycji do przedstawienia procesów własnej zmiany. Niedostatek tych umiejętności u dzieci powoduje, że przypisuje się im raczej procesy uczenia niż kształtowania. Ale czy za Bildung nie należy uznać nauczenia się czytania i pisania - umiejętności pozwalających radykalnie zmieniać relacje dzieci ze światem, niezależnie od tego, że uczestnicy badań nie mówią o opanowaniu tych czynności, bo traktują je już jako umiejętność oczywistą. Autorka stawia też szereg pytań, inspirowanych koncepcją struktur procesowych F. Schütze, m.in. od kiedy dorastający dysponują wiedzą kierującą ich działaniem? Kiedy i w jaki sposób w miejsce takiej wiedzy wkraczają biograficzne orientacje, będące projektami działania albo wyrazem sporu z instytucjonalnymi normami i społecznymi oczekiwaniami? Jeśli np. 10-latek mówi, że chce skończyć studia, to ujawnia swoją samodzielną orientację kształceniową czy wyraża normatywne oczekiwania swojego środowiska? Na ile można ujmować dziecięce i młodzieżowe procesy dorastania jako biograficzne trajektorie?

Punktem wyjścia artykułu Franka Beiera i Franziski Wyßuwa (Preskryptywne i refleksyjne interesy poznawcze w jakościowych badaniach lekcji i kursów) poświęconego badaniom jakościowym procesów lekcyjnych jest przypomnienie różnicy miedzy preskrypcją i deskrypcją. Przez preskrypcję rozumieją założenia leżące u podstaw obserwacji, które nie mogą być przez jej wyniki rewidowane, ponieważ konstytuują ją jako czynności odróżniania. Preskrypcyjne reguły określają, jak obserwować i jak powinno się ontologicznie ujmować jej przedmiot. Deskrypcje to mniemania konstruowane przez obserwację, mogą więc być w jej wyniku rewidowane. Każde badania empiryczne wprowadzają zarówno preskrypcje, jak i de- 
skrypcje, relacja między nimi uzależniona jest od konkretnego projektu. Wstępnie można przyjąć, że warunkiem nabycia nowej wiedzy jest zawieszenie preskrypcji w trakcie analizy. Ale sytuacja badań w pedagogice jest szczególna, ponieważ oczekuje się od nich wkładu w rozwiązywanie konkretnych problemów wychowawczych. Jeśli więc pedagogika ma kierować „poprawianiem praktyki”, to potrzebuje normatywnych podstaw dla rozróżnienia między dobrą i złą praktyką, co wzmacnia pozycje preskrypcji. Autorzy koncentrują się w swoim artykule na specyfice związku preskrypcji z interesami poznawczymi pedagogicznych badań jakościowych. Przyglądają się wybranym projektom badawczym w trzech aspektach: a) przedmiotowym - pytając, jak w tych projektach badawczych definiowany jest problem, który ma być empirycznie rozpoznawany; b) działaniowym - pytając o koncepcje rozwiązywania trudności; c) epistemicznym - do osiągnięcia jakiej wiedzy dąży dane badanie. W wyniku przyjęcia tych trzech poziomów analizy wyróżnili trzy metodyczne wzory jakościowych badań procesów lekcyjnych: normatywno-instrumentalny, problemowo-rekonstrukcyjny i refleksyjny.

Drugą część opracowania poświęconą teoretycznym innowacjom w badaniach jakościowych rozpoczyna Arnd-Michael Nohl (Pojęcia podstawowe $i$ empiryczne analizy jako wzajemne lustro: potencjał refleksyjnej relacji między teoriq podstawowq a rekonstruującq empiriq). Stawia pytanie, czy wykorzystywane w badaniach teorie podstawowe (np. teorie kształtowania, teorie habitusu) i przedmiotowe (np. relacje społeczne młodzieży) mogą być modyfikowane i na nowo strukturyzowane w wyniku owych badań. Opowiada, iż nie zdarza się to często, ale jest możliwe w przypadku, gdy uzyskane wyniki badań zrodzą wątpliwości. Przywołuje poglądy Charlsa Peirce, który zauważył, że prawdziwe zwątpienie nie powstaje przez prosty wysiłek woli, lecz jest wynikiem doświadczenia. Nohl uważa, że źródłem nowych doświadczeń mogą być wyniki badań empirycznych. Dzieje się tak, kiedy efektem badań jest opis empirycznego stanu rzeczy niemieszczącego się w teorii podstawowej, co wymaga wygenerowania nowej kategorii teoretycznej, a tym samym rozszerzenia teorii wyjściowej. W badaniach stosujących metodę dokumentarną tworzone są typik różnych stanów rzeczy, nierzadko modyfikujące teorie przedmiotowe. Jak długo teoretyczne pojęcia podstawowe i empiryczne analizy pasują do siebie, tak długo panuje spokój i zadowolenie wyrażające się w „przekonaniu", że tak właśnie jest. Jeśli jednak pojawi się nowy fenomen, pojawiają się również prawdziwe wątpliwości wobec odpowiedniości podstawowych pojęć.

Jeanette Böhme (Trendy, mity i standardy badań jakościowo-rekonstrukcyjnych - głos za powrotem metodologicznej przenikliwości w obszarze szkół metodycznych) dostrzega tendencję do relatywizacji szkół metodycznych (Methodenschulen), czego nie ocenia pozytywnie. Badacze coraz częściej informują, że zastosowali rozwiązania metodyczne wynikające $\mathrm{z}$ jakiejś metody, a nie, że zastosowali konkretną metodę. W efekcie niejasna staje się droga prowadząca do przedstawionego przez badacza sensu zdarzeń czy doświadczeń. Współcześnie nie toczą się znaczące spory metodologiczne, większe znaczenie, zdaniem Böhme, mają „mody na jakąś metodę” 
niż argumenty metodologiczne. Autorka jednoznacznie stwierdza, że teoretyczna neutralność badań jakościowych jest mitem, tak samo jak mitem jest przekonanie o bezzałożeniowej indukcji prowadzącej do mówienia badaczy „w języku przypadku". Teoria w badaniach rekonstrukcyjnych ma status heurystyki, tworzy warunki dla poznania, ale jednocześnie może być krytycznie przekształcana na podstawie empirycznej argumentacji. Osoby prowadzące badania rekonstrukcyjne winny tworzyć warunki dla intersubiektywnego rozumienia procesu badawczego, metodyczność postępowania ma służyć kontrolowanemu rozumieniu obcego.

Ruprecht Mattig (Logika badawcza Wihelma von Humbolta w studiach nad Baskami) odtwarza dwie formy abdukcyjnego wnioskowania zawarte w dziełach Humbolta poświęconych Baskom. Początkowo traktował on Basków jako kwintesencję pierwotnego i czystego charakteru narodowego, który może być punktem odniesienia dla innych nacji (zwłaszcza niemieckiej), pragnących kształtować pełnię swojego charakteru. Po kilku latach przedstawił jednak całkowicie inny obraz Basków. Uznał, że ich kultura i język, podlegając trwającej przez wieki skutecznej chrystianizacji, uległy różnorodnym przekształceniom. Mattig uważa, że początkowo Humbolt stosował „jakościową indukcję”, w ramach której badany przypadek (Baskowie) ujmował w znane już reguły. Dopiero potem zastosował wnioskowanie abdukcyjne i z posiadanych danych wyprowadził nową regułę.

Alexander Geimer i Jule Fiege (Innowacje vs. reprodukcje? Relacje teorii podstawowych, metodologii $i$ teorii odnoszonej do przedmiotu na przykładzie metody dokumentarnej) zwrócili uwagę, iż nikt już nie kwestionuje generowania teorii przedmiotowych na podstawie danych empirycznych. Wątpliwości dotyczą natomiast możliwości transformacji metodologicznych oraz metateoretycznych podstaw badań empirycznych. Autorzy rozważają to zagadnienie $\mathrm{w}$ odniesieniu do metody dokumentarnej. Pokazują, jak empiria i teoria „współdziałają” w dochodzeniu do teorii empirycznie ugruntowanych i „otwierających drzwi” na inną teorię. Dla scharakteryzowania różnych form relacji między danymi empirycznymi i teoriami wprowadzają metaforę „wchodzenia drzwiami frontowymi” i „drzwiami od tyłu”. Pokazują, że dane empiryczne modyfikują strukturalną teorię socjalizacji Urlicha Oevermanna i teorię uznania Axela Honnetha zgodnie ze wzorem wkraczania przez „tylne drzwi”. Natomiast koncepcja stylu życia opracowana przez Ralfa Bohnsacka ma „przesuwać frontowe drzwi” teorii działania, a koncepcja „hegemonialnych figur podmiotu" Alexandra Geimersa wprowadza metateoretyczne i metodologiczne innowacje do metody dokumentarnej.

Ostatnią część książki rozpoczyna Robert Kreitz (Interpretacje i inferencje), przedstawiając model analizy przekazu podczas lekcji (na przykładzie kursu dla dorosłych), która koncentruje się na pytaniu, jak uczniowie dzięki uczestnictwu w lekcji rozumieją coś, czego wcześniej nie rozumieli. Wykorzystuje instrumentarium analizy konwersacyjnej, uzupełnione analizą lekcyjnego współdziałania, z uwzględnieniem „konkluzji”, na które ukierunkowana jest lekcja. Jak wskazuje tytuł, kluczowymi pojęciami jest interpretacja i inferencja. Interpretacja służy 
rozumieniu czegoś, co ma sens i zależy od możliwości (Vermögen) interpretujących. W jej trakcie zachodzi proces inferowania. Kreitz określa inferencję jako wnioskowanie ze znanego o nieznanym, ponieważ identyfikowany sens nie jest wyprowadzany z tego, co jest percepcyjnie doświadczane. Procesy inferowania mają miejsce w życiu codziennym, wykorzystywane są także w badaniach jakościowych. Autor uznaje je za jedną z podstawowych operacji generowania poznania. Do badania interpretacyjnych inferencji szczególne nadają się takie dziedziny rzeczywistości społecznej, które są wynikiem interpretacji wytwarzanych w procesie komunikacji i współdziałania. Taką rzeczywistość stanowi nauczanie pod warunkiem, że w jego toku przekazywane są nowe znaczenia. Kreitz chce odtworzyć rozumienie za pomocą inferencyjnych procesów przyjmujących formę algorytmu, traktując to jako wkład w rekonstruowanie „gramatyki pedagogicznego działania”.

Dwa kolejne artykuły Thorstena Fuchsa (Transmisja i transformacja wartości w rodzinie między pokoleniami - rozważania nad projektem teorii empirycznie podbudowanej) i Dominika Krinningera (Perspektywy empirycznie podbudowanej teorii wychowania $w$ rodzinie) poświęcone są badaniom rodziny. Autor pierwszego zwraca uwagę na niedostatek dyskusji nad wartościami w pedagogice. Wprawdzie powszechnie akceptuje się ich ogromne znaczenie, ale w zasadzie nie ma odpowiedzi na pytanie, jak wartości się kształtują. Jeśli uzna się, że wartości powstają $\mathrm{w}$ procesie samokształtowania, poprzez identyfikowanie się z ważnymi osobami, ich światopoglądem i wartościami, to pierwszym miejscem, w którym możliwe są takie procesy, jest rodzina. Fuchs dokonuje przeglądu literatury, wskazując na teoretyczne wątki, które uznaje za inspirujące dla planowania badań empirycznych. Źródłem przesłanek teoretycznych mają być koncepcje Richarda Hönigswalda oraz Norberta Eliasa, natomiast metodą badawczą biograficzne wywiady rodzinne wg Bruno Hildenbranda. Dominik Krinninger skupia się na procesach wychowania w rodzinie, zwracając uwagę, iż nigdy nie było tak wielu form rodzinnych jak obecnie. Trudno jest więc opisać cechy strukturalne rodziny. Krinninger traktuje wychowanie w rodzinie jako znaczącą pedagogicznie praktykę, o ile ma ona znaczenie dla osobowego stawania się człowieka. Tworzy elementy empirycznie podbudowanego teoretycznego modelu wychowania w rodzinie, korzystając z wyników różnych badań. Swoje postępowanie nazywa „teoretyzowaniem rekursywnym", w którym teoretyczne dyskursy łączone są z empirycznymi danymi w nowe teoretyczne „figury”.

Dominik Wagner (Teoretyczne ukierunkowanie $w$ biograficznej rekonstrukcji przypadku) rozpoczyna swój artykuł od zasygnalizowania stanowisk dotyczących roli teorii w badaniach biograficznych. Jako przykład biograficznej metody rekonstrukcji przypadku niedopuszczającej wstępnej teorii przedstawił metodę Gabrieli Rosenthal. A jako alternatywną propozycję Ingrid Miethe, która przyjmuje wstępne teoretyczne ukierunkowanie rekonstrukcji przypadku. Odwołując się do własnych badań, sygnalizuje trudności pojawiające się w ramach każdej z metod. 
Prezentowane opracowanie nie stanowi łatwej lektury, zwłaszcza dla czytelniczek i czytelników, którzy nie znają szczegółowych teorii i metod badań jakościowych przywoływanych - a nieomawianych - przez autorki i autorów artykułów. Poszczególne teksty sygnalizują przyjmowane przez ich autorów założenia i wyprowadzane $\mathrm{z}$ nich konsekwencje, przedstawiają rozwiązania przyjmowane w konkretnych badaniach. Może być to źródłem inspiracji dla planowania i prowadzenia szeroko rozumianych badań edukacyjnych. Moim zdaniem książka jest interesująca zwłaszcza dla tych, którzy nie tylko są zainteresowani problematyką Bildung, ale także warunkami tworzenia pedagogicznej wiedzy naukowej, w tym wiarygodnością poznania wykorzystującego empiryczne dane jakościowe. W polskiej pedagogice badania jakościowe są podejmowane dosyć często, znacznie rzadziej ich wyniki zmierzają w kierunku budowania teorii przedmiotowej. 